articles

\title{
Entrepreneurial Orientation and Startup Performance in Technology Business Incubation: Mediating Role of Absorptive Capacity
}

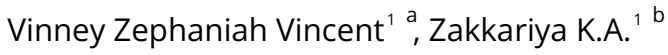 \\ 1 School of Management Studies, Cochin University of Science and Technology \\ Keywords: Entrepreneurial orientation, start-ups, business incubation, absorptive capacity, performance \\ https://doi.org/10.53703/001c.29837
}

\section{Journal of Small Business Strategy}

Vol. 31, Issue 5, 2021

\begin{abstract}
The entrepreneurial orientation (EO) literature verifies its positive relationship with firm performance; nonetheless, its degree relies on certain factors. This study uses the knowledge-based view to develop and test a model of how start-ups can enhance their entrepreneurial orientation (EO) in incubator environments. Based on the concept of dynamic capabilities and strategic fit, this study proposes that absorptive capacity (ACAP) plays a role in catalyzing EO to yield performance outcomes. Only when start-ups combine existing resources with the absorptive capacity to make use of their strategic decisions, can they achieve a higher EO. The research model is empirically validated using survey data from 304 start-ups of various technology incubators in India. Our research evidence prove that ACAP improves the relationship between EO and performance in incubator environments. Further, we discuss implications for theory and practice.
\end{abstract}

\section{Introduction}

One of the main motivators of entrepreneurship actions is the creation of successful start-ups (Taormina \& Lao, 2007). The emphasis on successful new venture stories has led many entrepreneurs to work and discover the components and characteristics of a successful start-up (Dubini, 1989). Although objective conditions, such as human capital (Dimov \& Shepherd, 2005), intellectual capital (Pena, 2002), social support (Hopp \& Stephan, 2012), and financial capital (Fitza et al., 2009) have been found to have a positive impact on start-up performance, subjective factors, such as learning orientation (Ebrahimi et al., 2018), market orientation (Lewrick et al., 2011; Mavondo et al., 2005; Renko et al., 2009) innovation (Kohtamäki et al., 2020; Stayton \& Mangematin, 2016; Caseiro \& Coelho, 2019) have also been shown to increase start-up performance. These findings have highlighted the 'subjective' nature of firm performance, which indicates that successful and unsuccessful entrepreneurs tend to show variations in their strategies of ideation, knowledge building, interpretations, and thought processes under varying subjective conditions (George \& Bock, 2011; Davidsson, 2015; Bradley et al., 2012; Gregoire et al., 2011).

Subsequently, small firm performance has been found to be correlated with a number of firm-level variables that are subjective in nature, such as small business orientation
(Runyan et al., 2008), firm structure (Pelham \& Wilson, 1995) and team creativity (Khedhaouria et al., 2015). Research has identified absorptive capacity as one of the predictors of new venture performance (Flatten et al., 2011; Patel et al., 2015; Sciascia et al., 2014; Zahra \& Hayton, 2008) indicating the nature of the learning ability that characterizes absorptive capacity (Sciascia et al., 2014) may have a beneficial effect on spawning and creating innovation, which may potentially lead to innovative technology products which cause performance in startups (Zahra \& George, 2002).

On the other hand, research is still limited with regard to the strategic constructs that make some start-ups more susceptible to higher absorptive capacity (Flatten et al., 2011). Recent research suggests that entrepreneurial orientation, a well-known construct of strategic entrepreneurship, can be an answer to this question, as it can be a source of firmlevel decision-making activity that characterizes the knowledge building capacity (Engelen et al., 2014) which may lead a startup to broaden its market opportunities. Consequently, it seems reasonable that the creative recombination of information flows will induce productive entrepreneurial actions (Sciascia et al., 2014). In high-tech firms, EO built with poor access to external information and networks, despite the importance of market knowledge for the recognition and retention of highly attractive market segments, will hardly translate into good outcomes (Engelen

\footnotetext{
a Kerala, India, vinneyzephaniah@gmail.com, +919656850900

b Kerala, India, zakkariya@gmail.com
} 
et al., 2014). Furthermore, the high risks of rapid innovative changes in a technology market, faced in start-up industries, would seriously undermine EO's output payoffs if established without a constant method of assimilating and leveraging tacit knowledge to generate realistic innovation (M. Hughes \& Morgan, 2007). Especially in technology prone industry, start-ups face a high level of imitation, which can only be overcome through unique products that provide real-time solutions for customers, which can be realized only through the live exploration of knowledge and information (Chaudhary, 2019; Vanhaverbeke et al., 2012).

At the same time, it is often difficult and challenging to transform and catalyze entrepreneurial orientation into improvements in firm performance (Dess et al., 1997). Researchers have therefore called for further developments in the analysis of how entrepreneurial orientation can be converted into increased firm performance (Hou et al., 2019; Keh et al., 2007; Lumpkin \& Dess, 2001; Madsen, 2007) by considering the aspects that might stimulate this process (Dess \& Lumpkin, 2005; Lumpkin \& Dess, 2001; Stam \& Elfring, 2008). Considering the characteristics of the Absorptive capacity (ACAP) as learning ability and also regarding its prognostic power on new venture performance, the authors thought of exploring the relationship between EO and ACAP in predicting the startup performance. Therefore, it is argued that EO may not be beneficial to the company in these settings unless it has established high levels of absorptive capacity. Consequently, this study responds by centering on absorptive capacity. A firm's success may depend on its absorptive capacity, which determines its ability to explore, assimilate, and apply new knowledge to its operations (Jansen et al., 2005; Zahra \& George, 2002).

While the potential of absorptive capacity to assist earlystage companies is evident and persuasive, the degree to which it enhances the learning ability of start-ups through exploration, and transformation of opportunities via exploitation of new and existing knowledge is unidentified. Therefore, this article discusses this topic in greater depth. In particular, its aim is to examine how entrepreneurial orientation act as a strategic construct that can utilize the knowledge attribute to help improve the survival of new technology start-ups through higher performance. Thus, the study examines the mechanism by which the start-ups absorptive capacity enables EO by allowing the exploration of knowledge and critically promoting the transformation of information into resources that promotes business performance through innovation, creating sustainable development. Empirically, this study is built on survey data collected from incubator firms from various technology business incubators in India. The context of the incubator is consistent with the literature on start-up performance and new venture efficiency, which suggests that the relationship between them may be nexus and dependent on situational variables.

Consequently, these incubator start-up firm's provide the right context for analyzing the association amongst entrepreneurial orientation, absorptive capacity, and start-up performance, since most of them are new and emerging and have no initial sales. The rest of the article is arranged in four sections. First, we clarify the notions of entrepreneurial orientation, absorptive capacity, and start-up per- formance. Secondly, we propose a relationship between them. A third section, which discusses the research methodology and the empirical results, follows. Ultimately, it discusses managerial and theoretical implications.

\section{Theoretical Background and Hypotheses Development}

\subsection{Entrepreneurial orientation and startup performance}

Incubators are often set up with the goal of fostering economic development in their local region by supporting start-ups and companies that will create jobs and also creating a more vibrant local business ecosystem (Grimaldi \& Grandi, 2005; Wu et al., 2020). Not only do they enable new entrepreneurs to start their business by promoting rapid innovation, but they also promote their opportunities for survival and success by building strategic capacity, knowledge, and networks (Aernoudt, 2004). Best practices illustrate the need to integrate the incubator programs correctly with the overall performance development strategy, where incubators are designed and implemented to achieve specified goals as part of, or as a combination of, larger strategic capability, and orientation (Hackett \& Dilts, 2004a).

Start-up performance is a key target for incubators and incubator companies alike. By helping incubated firms build new products and processes in a competitive market, they are meant to generate success through technology advancements (Al-Mubaraki \& Busler, 2013). In addition, an incubator should help start-ups to increase the likelihood of survival, even post-incubation, by paving a sustainable path (Carayannis \& Von Zedtwitz, 2005). To achieve the aim of sustainability, start-ups should not only be able to innovate but be able to take strategic decisions grounded on knowledge and skills for opportunity recognition and exploration of the real-time market (Campbell \& Allen, 1987).

Several literature streams focus on objective measures of start-up performance or new venture performance (Ayatse et al., 2017; C.-J. Chen, 2009; Clausen \& Korneliussen, 2012; Iyortsuun, 2017; Schwartz, 2013). Although researchers often use interchangeable terminologies (e.g., growth, profits, turnover), they all focus on the importance of financial measures in the performance of start-ups. However, pursuing this model in measuring "incubator firm success" can be meaningless, as it follows the conventional ways of measuring success in any business unit and is often as simple as interpreting an annual report or profit and loss statement (Voisey et al., 2006). The performance can be assessed with financial and non-financial indicators, according to Venkatraman \& Ramanujam (1986). Since the majority of the incubators are nonprofit organizations, they are amenable to additional outcomes since they are aiming at economic regeneration and sustainable development. As argued by Voisey et al. (2006) and Stephens \& Onofrei (2012), consideration of non-financial outcomes (soft measures) provides a valuable explanation for the growth of the incubator firm and provides a clearer, more comprehensive view of its performance.

A knowledge gap in the start-up performance literature is that most start-up performance studies are evaluated with only the hard measures (financial outcomes) in mind, 
leaving aside soft measures (non-financial outcomes) that are perceived to be decisive factors for small firm success. According to Voisey et al. (2006), the assessment of incubator firm performance must be wider than a collection of statistical outputs. Thus consistent with the approaches and measurement of Voisey et al. (2006) and Stephens \& Onofrei (2012), it is hence desirable to use both hard and soft measures in this study to quantify incubator start-up performance.

Firm failure is highest when firms are small; the implementation of effective strategies is essential for success (Lechner \& Gudmundsson, 2014). Incubator firms have an advantage from access to ideas and knowledge to strategic decision making (Voisey et al., 2006). In line with this, we focus on the context of start-up performance at the incubator firm-level and focus in particular on the role of strategic structures that may foster performance. Entrepreneurial orientation is a term that emphasizes the role of externally driven strategies, as well as the importance of management support as a driving force behind the small firm success (Lumpkin \& Dess, 1996). EO can be argued not as a mere performance enhancement tool but as self-catalyzing for the entire good if introduced under the right circumstances (Miller, 2011) in a start-up firm (Clausen \& Korneliussen, 2012). On the other hand, in some situations, EO can even be disadvantageous for start-ups if the firm's context does not suit the application of EO (Lyon et al., 2000). Contrary to such a view, this paper argues that entrepreneurial orientation could be a significant antecedent of start-up performance among incubator firms, as incubators provide the right entrepreneurial context for firm-level strategic orientation.

The original interrogation raised by Miller (1983) - How does entrepreneurship vary in different firms? We aim to provide a logical extension so that the very concept of entrepreneurship and EO can be demonstrated. EO is related to a firm's willingness to engage in entrepreneurial behavior (Dess \& Lumpkin, 2005). This can be done when a new or existing product is introduced into a new or current market, or still, if a new business is launched (Kraus et al., 2012). Thus EO serves as a major antecedent for incubator startups as they are in their early stage and have no initial product, sales, or revenue at all (Clausen \& Korneliussen, 2012; Shi et al., 2020; Wu et al., 2020). Also, these start-ups are prone to failure owing to their liability of newness, and differ in terms of their performance and growth as well (West \& Meyer, 1998).

EO refers to a firm's degree of entrepreneurship, and the variation in the performance of start-up solely depends on the degree to which they adopt different ways of pursuing entrepreneurship (Walter et al., 2006). The difference between start-ups in pursuing entrepreneurship can be explained by their entrepreneurial orientation since it refers to the method, practices, and decision-making activities that lead to the critical actions (Lumpkin \& Dess, 1996). Though start-ups in a business incubation facility receive homogenous services, they differ in their performance due to their strategic decision making characteristics (Clausen \& Korneliussen, 2012; Hou et al., 2019; Shi et al., 2020; Wu et al., 2020). Therefore it is best to attribute that the startup performance of incubator firms can be analyzed within the context of entrepreneurial orientation, which allows us to relate to what degree of entrepreneurship has led to variations among them.

Centered on the initial conceptualization of Miller (1983), researchers largely approve of the three dimensions of EO, namely risk-taking, innovativeness, and proactiveness (Covin \& Wales 2018; Rauch et al. 2009; Wales et al., 2013). Lumpkin \& Dess (1996) recommend competitive aggressiveness and autonomy as two additional dimensions of the EO construct. Lumpkin \& Dess (1996) suggest that further insights are to be gained from studying all the dimensions concerning EO. The breadth and depth of EO research continue to expand as the term is applied to understand the effects of being entrepreneurial across a rising number of research contexts, which consider it a core firm strategic orientation (Covin \& Miller, 2014). To better comprehend the nature of EO-performance relationships and to inhibit unreliable short and normative theory construction, the specific relationships between EO and firm performance should be considered (Green et al., 2008; Linton, 2019). Lumpkin \& Dess (1996) found that all the dimensions of EO may be present when a business enters a new market, which is a necessary act of entrepreneurship because each one of it plays a significant role during a new entry into the market which appropriately represents the case of an incubator firm. For researchers to understand entrepreneurship and entrepreneurial behavior in a different context, it is better advised to regard EO as a uni-dimensional and independent construct (Rauch et al., 2009; Clausen \& Korneliussen, 2012). Consequently, the present study considers the sub-dimensions to be related (Lumpkin \& Dess, 1996), and nonetheless, the sub-dimensions will be deliberated in detail below for a clearer picture.

Lumpkin \& Dess (1996) opines that innovativeness is the propensity of a firm to encourage and support novel ideas, development, experimentation, and creative processes that can lead to new technological products, services or processes. Lumpkin \& Dess (1996) see innovativeness as an important component of EO because it represents an effective means of pursuing new opportunities for businesses. Covin \& Miles (1999) claim that innovativeness is the main dimension to be utilized in all start-up and entrepreneurial firms. According to them, even in the midst of other dimensions, there is no firm-level entrepreneurship, if innovativeness is not employed.

A significant number of researchers have found a positive relationship between innovativeness and small firm performance (Rauch et al. 2009; Justine et al. 2005). Start-ups face a lot of imitation globally, and the realness among start-ups will have implications for their performance. Subsequently, the significance of innovativeness as a component in EO for explaining performance is undeniable (Omisakin et al., 2016).

Risk-taking and the dimensions of entrepreneurial behavior are mostly seen as synonymous. "Risk-taking is the degree to which entrepreneurs are prepared to make significant and risky decisions, which can lead to high amount of failures" (Miller \& Friesen, 1978, p. 923). Wiklund \& Shepherd (2003) advocate that risk-taking attitude is a company's ability to commit and invest valuable resources in a new venture where the result may be highly appalling. 
Pro-activeness in a firm allows it to work opportunistically to change the environment by driving trends and stimulating demand and becomes a first mover in a competitive environment (Polonsky et al., 2005). Proactive firms take the initiative in leveraging resources and become market leaders. Such businesses exploit resources, find market opportunities, and create new market segments that need innovation and experimentation (Fayolle et al., 2010). Proactive firms perform better than rivals as they identify opportunities way ahead of their rivals and adapt to market changes accordingly in a rapid fashion (Franco \& Haase, 2013; Linton, 2019).

Competitive aggressiveness represents the strength of a company's attempt to beat their market competitors, marked by a strong and offensive competitor behavior (Lumpkin \& Dess, 2001). Competitive aggressiveness is the strength of a company's attempts to outperform competitors in the market, marked by a combative disposition and a strong response to competitor behavior (M. Hughes \& Morgan, 2007). Competitive aggressiveness relates to a firm's tendency to threaten its opponents aggressively and strongly to enter the market or boost its role, which is, to outperform its rivals (Chang et al., 2009). Competitive aggressiveness of firms endorses improved firm performance (Chang et al., 2009; Lyon et al., 2000).

Autonomy is an independent activity by a person or team designed to create and carry through a business model from entry to completion (M. Hughes \& Morgan, 2007). It represents a person's strong desire to have independence in creating and executing an idea within a firm (Lumpkin \& Dess, 2001). Indication of autonomy in organizations can differ depending on size, management style, or ownership (Coulthard, 2007). Various studies and empirical evidence have shown that autonomy improves the positive performance of the company (Omisakin et al., 2016).

Clausen \& Korneliussen (2012) had conducted a study on EO and speed to market among incubator firms, where they have adopted EO as a unidimensional construct. Rauch et al., (2009) also states that it is premature to recommend a multidimensional conceptualization of entrepreneurial orientation, as yields truer results by considering EO as a unidimensional concept. Thus, we intend to adopt the same treatment for EO in this study, by considering it as a unidimensional construct. The following research question is hence posed: to what extent is entrepreneurial orientation related to firm performance for incubator firms? Based on the above argument, it is hypothesized that:

$\mathrm{H} 1$ : There is a positive relationship between EO and incubator start-up performance

\subsection{Absorptive Capacity and start-up performance}

The resource dilemma of a start-up firm limits its entrepreneurial actions, so they have to make meaningful use of the opportunities required to create value and improve performance. The firm must be able to connect acquired external knowledge with its product markets in a substantial way (Cohen \& Levinthal, 1990) as it will face resource decline over time as the firm meets its original needs and continues to build its own capabilities. However, that is less likely to be true in the context of incubator start-ups. They exist in an environment that is marked by the fast and continuous change which create motives for continuous learning from incubators (Hutabarat \& Pandin, 2014). This type of change allows firms to keep learning to survive, let alone succeed (Patton, 2014). This, in effect, allows firms to learn from highly experienced mentors and professional peer networks to promote the growth of their own knowledge, skills, and capabilities (Grandinetti, 2016). Consequently, the continuous creation of the ability to absorb the knowledge within the firm is a necessary condition for the productive use of knowledge outside its boundaries by a firm (Flatten et al., 2011).

Absorptive capacity is the culmination of a prolonged investment and knowledge acquisition cycle within the firm, and its progress is path-dependent (Wales et al., 2013). Every piece of new knowledge that a firm has gained will contribute to performance and innovation (Zahra \& Hayton, 2008). Out of a learning context, ACAP has been theorized to contribute to firm growth by enhancing knowledge transfer and, in effect, to promote sustainable competitive advantages (Grandinetti, 2016; Hutabarat \& Pandin, 2014). Prior empirical investigations have mostly provided support for the idea that the ability to recognize and recreate new knowledge acquired from outside sources leads to better firm performance (Y.-S. Chen et al., 2009; Cohen \& Levinthal, 1990; Zahra \& Hayton, 2008).

Cohen \& Levinthal (1990) describe absorptive capacity as the ability of a start-up to explore, understand, transform, and assimilate the knowledge acquired from external sources. According to Lane et al. (2006), “absorptive capacity is a firm's ability to utilize externally held knowledge through three sequential processes: (1) recognizing and understanding potentially valuable new knowledge outside the firm through exploratory learning, (2) assimilating valuable new knowledge through transformative learning, and (3) using the assimilated knowledge to create new knowledge and commercial outputs through exploitative learning". Though other ACAP frameworks are available (e.g., Zahra \& George, 2002), we use the system of Lane et al., 2006, since it is a learning-oriented framework which advances a developing point for undertaking a more comprehensive model of the firm's absorptive capacity which includes its drivers in addition to its outcomes (Lane et al., 2006; Tzokas et al., 2015). Its focus on exploratory learning via new knowledge as well as the exploitation of the existing, and the combination of the two through transformative learning is specifically useful in the context of incubator start-ups that promote technology advancements, through innovative new products and services (Gebauer et al., 2012; Monteiro et al., 2019; Patton, 2014), such as the incubator startups focused in this study.

Exploratory learning is used to identify and comprehend new external knowledge (Jansen et al., 2005). When the strategy of a firm directs its efforts, the firm's prior knowledge, which is a function of existing models, affects the significant assessment of new external information (Tzokas et al., 2015). Transformative learning requires several mechanisms that influence how the newly acquired knowledge and the existing are integrated (Jansen et al., 2005; Lane et al., 2006). Knowledge management processes influence 
how such knowledge is distributed and passed to various parts of the firm (Argote et al., 2003). The overall outcome of these processes is a transformation of the collective nature of different organizational divisions arising from the assimilation of new knowledge (Jansen et al., 2005; Lane et al., 2006; Tzokas et al., 2015). Ultimately, the last dimension reflects on how exploitative learning is used to enforce the assimilated external knowledge (Lane et al., 2006).

Hence recapitulating, absorptive capacity is the ability of the firm to utilize knowledge held externally through prior relevant knowledge, new knowledge scanning, internal and external networks (Jansen et al., 2005), which is very much relevant in the incubator context. It involves a path from identifying and acquiring external knowledge through networks, understanding, and applying prior and new knowledge to generate performance outcomes (Roberts, 2015). It is important to note that an incubator offers the network requirements for knowledge building and sharing (Patton, 2014). Thus, the incubator environment allows the firms to improve the process of exploration, transformation, and exploitation of knowledge to achieve sustainable goals(Jansen et al., 2005). Such development makes it possible for a firm to forecast more accurately the nature and commercial prospect of successful business models (Cohen \& Levinthal, 1990) and thus to develop more specialized innovative products (Tzokas et al., 2015), which in turn leads to improved new product performance measures. It is, therefore, best to assume that, absorptive capacity as the combination of the abovementioned sub-dimensions will have a positive impact on start-up performance, and hence we hypothesize that:

H2: There is a positive relationship between ACAP and incubator start-up performance.

\subsection{Entrepreneurial orientation, Absorptive Capacity, and Start-up performance}

Generally, the formal framework of a firm restricts the search for new knowledge, keeping engrossed in the knowledge that is attuned with what the firm already knows (Zahra \& Hayton, 2008). But this does not apply for startups and new ventures who are in their early stages and does not have a definite formal structure owing to their newness (Tzokas et al., 2015). Particularly for incubator firms, several internal and external strategic factors have the ability to define a firm, to change the knowledge orientation of the firm and to change the company's resource allocation patterns and performance (Grimaldi \& Grandi, 2005). The knowledge-based view can offer an explanatory model on how these incubators function as specialized supporting units that upkeep new businesses by providing intangible resources, such as knowledge and networks through physical co-location (Becker \& Gassmann, 2006). The knowledge-based view is an extension of the resource-based view, emphasizes the learning and creation of new knowledge in an organization, sharing the knowledge, transferring knowledge, and its application to real-time situations (Grant, 1996). Thus, the development and sharing of knowledge are of key significance in the incubation process (Tsai et al., 2009). The knowledge-based view is principally used to explain the existence of the firm (Grant, 1996), concomi- tant with the strategic fit framework (Kim et al., 2012; Theriou et al., 2009, 2014). Certain decisive strategic constructs display decision making characteristics of firm existence (Zahra \& Hayton, 2008). Strategic fit expresses the degree to which a firm is toning its resources and capabilities according to the prospects in the external environment (Harrison \& Pelletier, 1998).

Strategic fit is as well related to the resource-based view of the firm (Eisenhardt \& Schoonhoven, 1996), which suggests that the key to performance is to utilize the unique characteristics of the firm's range of resources and capabilities which can eventually be developed into its own competitive advantage (Colbert, 2004; Newbert, 2008; Yamakawa et al., 2011). EO is the most extensively studied firm-level strategic construct that enables firms to translate various resources and capabilities into greater firm performance (Rauch et al., 2009). However, according to the strategic fit concept, it is imperative to differentiate between resources and capabilities (Eisenhardt \& Schoonhoven, 1996).

Resources related to the inputs to ideas owned by the firm, whereas capabilities describe the accumulation of learning the firm embraces (Theriou et al., 2009, 2014). EO stimulates the motivation of a firm towards entrepreneurship and can improve key firm resources (Clausen \& Korneliussen, 2012), which outlines the opportunities of a strategic fit framework. Start-ups with appropriate EO, be acquainted with how to search for knowledge-based resources and opportunities, can tap possible opportunities and thus generate its value propositions (Cohen \& Levinthal, 1990), but unless the start-up is willing to absorb and exploit the knowledge with commitment, then the opportunities for improvement remain underplayed (Sciascia et al., 2014).

Having said that, knowledge is, in fact, hard to perceive and comprehend (Kintsch, 1988). This is especially true when it comes to the tacit knowledge that people learn through doing or evolving as they discover new ways of doing things (Yli-Renko et al., 2002). The dynamic capabilities view considers firms as real-time initiators of resources by which managers create, incorporate, and redesign internal and external capabilities to address fast changing environments (Ambrosini et al., 2009; Barreto, 2010; El Hanchi \& Kerzazi, 2020). Accordingly, incubator start-ups are in a highly fluctuating complex environment, which demands a splurge of technological advancements (C.-J. Chen, 2009). It is necessary for them to assimilate, construct, and update both its in-house and peripheral competencies to address quickly changing environments for the active generation of competitive resources (Grimaldi \& Grandi, 2005). This undeniably explains the relevance of dynamic capabilities in our study context. Entrepreneurial firms with significant EO succeed in exploiting the knowledge inherent in their dynamic capabilities to capture and leverage new knowledge by developing new products and services (El Hanchi \& Kerzazi, 2020; Miles \& Arnold, 1991; Park \& Xiao, 2020). Absorptive capacity, which is best known as the dynamic capability of a firm, is its ability to identify, transform and apply the value of existing, external knowledge to commercial ends is vital to its performance capabilities (Zahra \& George, 2002).

Absorptive capacity is the ability of the firm to utilize 
knowledge held externally through exploratory learning, transformative learning, and exploitative learning (Tzokas et al., 2015). Absorptive capacity extends the firm's cognitive map and opens it to new ideas, which are vital for long-term success (Sciascia et al., 2014). As an organizational strategic capacity, EO improves the ability of the firm to participate in search behavior (Wales et al., 2013), and ACAP as a dynamic capability helps improve search outcomes as it acts as a boundary-spanning knowledge absorption ability (Jansen et al., 2005; Patton, 2014; Zahra \& George, 2002). Entrepreneurial orientation enables the firm to adopt an innovative and proactive behavior that allows it to create new knowledge that is necessary to attain new, distinctive capacities (Patel et al., 2015). Higher levels of EO, combined with absorptive capacity, promote efforts to integrate various components of knowledge (Engelen et al., 2014).

Thus, an important measure of how companies use knowledge-based tools to identify and leverage new opportunities could be due to entrepreneurial orientation (Wiklund \& Shepherd, 2003). Sciascia et al., 2014, proposes a framework for generating useful knowledge established by the effect of entrepreneurial orientation on absorptive capacity. A firm may be innovative risk-taking, proactive competitively aggressive, and possess autonomy, but catalyzing all of it to result in success depends on the nature and volume of external knowledge (An important message from past studies is that it offers an incomplete picture simply by looking at the direct effect of EO on firm performance ( del Mar Fuentes-Fuentes et al., 2015; P. Hughes et al., 2018; Li et al., 2009; Wales et al., 2013; Wang, 2008). Furthermore, Lumpkin \& Dess (1996) discuss that in order to be entrepreneurially oriented, a firm should achieve greater values of pro - activeness, risk-taking, autonomy, aggressiveness, and innovativeness. The judgments indicate that ACAP must be in place to capitalize on the effect of EO on performance and that ACAP is a key construct, along with EO, to differentiate begetters from fosterers. Therefore as discussed above, entrepreneurial orientation has a positive impact on absorptive capacity, and the latter increases the performance of startups. In other words, the effect of entrepreneurial orientation on start-up performance is most likely to be comprehended through the mediating effect of absorptive capacity. Based on the arguments above, we suggest the following hypotheses:

H3: ACAP significantly and positively mediates the relation between entrepreneurial orientation and incubator start-up performance.

The relationships expressed through the three formulated hypotheses are represented in our research model (see Figure 1).

\section{Methodology}

In order to test and prove the hypothesized relationships between EO, ACAP, and SP empirically, the researchers have adopted a descriptive research design using survey data obtained from incubator firms. Survey data was gathered in the context of government-supported technology business incubators in India. These incubators are open to enterprises with a new product idea and are established for less than five years. An important goal of the technology business incubator system is a technology development and the commercialization of new innovative products (Clausen \& Korneliussen, 2012). This background is appropriate in testing the influence of entrepreneurial orientation on start-up performance in the context of absorptive capacity. Hence the population of the study is defined as the CEO's of the technology-based startups incubated in government-supported technology business incubators in the state of Kerala, India. There were 540 such startups incubated in 32 technology business incubators established within the major cities of the state of Kerala.

\subsection{Data Collection}

A list of firms with the names and e-mail addresses of the CEOs were obtained from respective incubator managers, and also from the government agency that supports the technology business incubators. Following a census survey method, survey questionnaires were directly administered to all the 540 CEOs (forwarded to those founders who had been out of the station) for collecting the required data. All incubator managers were asked to remind the founder CEOs inside their incubation facility to respond to the survey questionnaire. Researchers were able to collect 304 valid responses out of 540 incubated businesses, following numerous updates and visits. This reflects a response rate of 64 percent, which is a much higher rate than in most other survey-based research that aims at new ventures and start-up firms. Some of these respondents started up ventures right after college; few are still in college; the majority of them worked with corporates before starting their own business. The demographic profile of the respondents is shown in Table 1.

\subsection{Measurement}

For entrepreneurial orientation (independent variable), we adopted the scales of M. Hughes \& Morgan (2007), which is based on an incubator firm context, and which is why it was considered apt for the study. It encompasses all the five dimensions of EO involving 18 items. The items were measured by a five-point Likert-type scale ranging from $1=$ strongly disagree to $5=$ strongly agree, with greater values representing higher amounts.

Existing new venture literature identifies three important indicators for absorptive capacity (mediating variable), including exploratory, transformative, and exploitative learning. Therefore for measuring absorptive capacity, we adopted the scales of Tzokas et al., (2015), which includes 11 items. All items were measured by a five-point Likerttype scale ranging from $1=$ strongly disagree to $5=$ strongly agree.

The scales of Voisey et al. (2006) and Stephens \& Onofrei, (2012) have been adopted for measuring start-up performance with the objective of synthesizing scales from the literature for hard and soft measures of start-up performance. The synthesized scale consisted of a total of 15 items: out of which the first 8 items are hard measures from Voisey et al. (2006) and 7 items are soft measures from Stephens \& Onofrei, (2012). The items of startup performance are measured on a five-point Likert scale, anchored 
Table 1. Demographic Profile of Respondents

\begin{tabular}{|l|l|c|}
\hline \multicolumn{1}{|c|}{ Variable } & \multicolumn{1}{c|}{ Category } & Percent \\
\hline \multirow{2}{*}{ Firm Age (In Years) } & \multicolumn{1}{|c|}{66.6} \\
\hline \multirow{2}{*}{ Gender } & $>2$ & 33.4 \\
\cline { 2 - 3 } & Male & 91.6 \\
\cline { 2 - 3 } & Female & 8.4 \\
\hline \multirow{2}{*}{ Education } & Completed & 82.6 \\
\cline { 2 - 3 } & Not completed yet & 17.4 \\
\hline Previous Start-up Experience & Had Former Start-ups & 79.1 \\
\cline { 2 - 3 } & No Former Start-ups & 20.9 \\
\hline Previous Work Experience & No Work Exp & 19.2 \\
\cline { 2 - 3 } & Work Exp & 80.8 \\
\hline Family-owned Business & Family has business & 28.2 \\
\cline { 2 - 3 } & No Family business & 71.8 \\
\hline
\end{tabular}

Table 2. Results of reliability test

\begin{tabular}{|l|c|c|c|}
\hline Variable & No of Items & Total of the accounted variance (\%) & Cronbach's Alpha \\
\hline Entrepreneurial orientation & 18 & 21.584 & .929 \\
\hline Absorptive capacity & 11 & 39.296 & .912 \\
\hline Start-up Performance & 15 & 54.947 & .951 \\
\hline
\end{tabular}

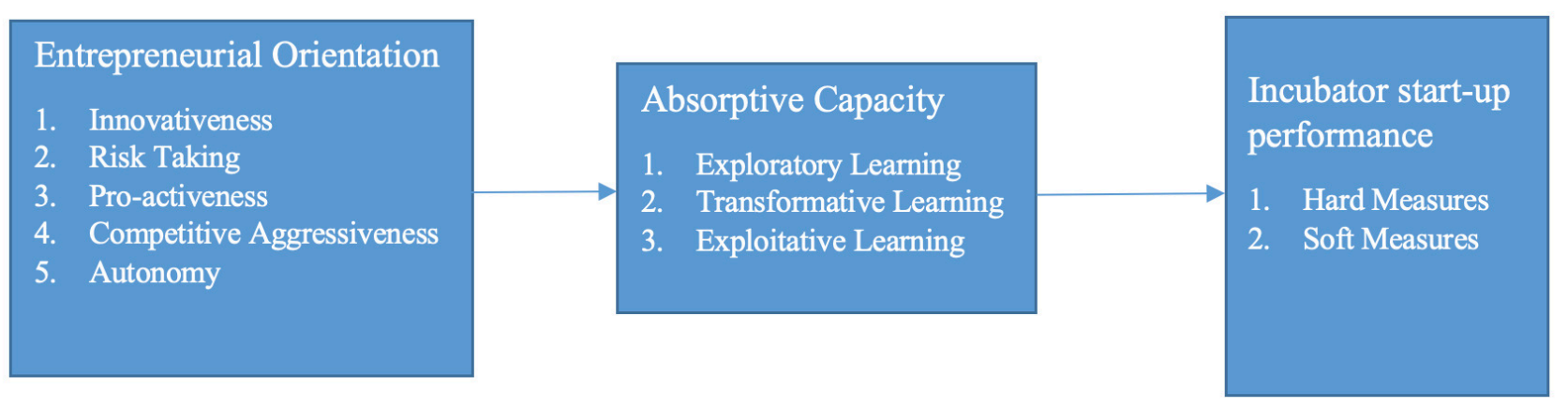

Figure 1. The research model.

by the lowest score as 1 and the highest score as 5 . A summated scale has thus been created.

\subsection{Control Variables}

The technology incubators in this study are well been equipped to incubate and facilitate startups in India. The facilities offered by these incubators typically include business-consulting network, technological and management assistance, mentoring, training, access to financing, flexible and low-cost leases, and office services (Grimaldi \& Grandi, 2005; Voisey et al., 2006). In the entrepreneurship literature, business incubation has been positively associated with startup performance (Hackett \& Dilts, 2004a, 2004b,
2008; Iyortsuun, 2017; Pena, 2004; Vanderstraeten \& Matthyssens, 2010; Voisey et al., 2006). Therefore we control for the business incubation services offered to incubator startups, especially in terms of resource munificence and monitoring and business assistance intensity (Hackett \& Dilts, 2008) of the incubators, as it could influence their entrepreneurial orientation, absorptive capacity as well as their firm performance.

Data were collected for several other control variables, too, such as firm age, CEO gender, education, prior startup experience, prior work experience, and family entrepreneurial experience. We controlled for the firm age and gender since both are two significant basic features that may be associated with firm performance. Age is measured by 
Table 3. Descriptive Statistics and Correlations

\begin{tabular}{|c|c|c|c|c|c|c|c|c|c|c|c|}
\hline & Mean & S.D. & & & & & & & & & \\
\hline $\begin{array}{l}\text { Start-up } \\
\text { Age }\end{array}$ & 1.33 & .472 & 1 & .007 & $-.180^{* *}$ & -.046 & .017 & -.035 & -.034 & .057 & .020 \\
\hline Gender & 1.08 & .278 & .007 & 1 & -.029 & -.053 & -.012 & .027 & -.036 & .015 & -.019 \\
\hline Education & 1.17 & .380 & $-.180^{* *}$ & -.029 & 1 & -.011 & $-.399^{* *}$ & .050 & -.078 & .009 & -.078 \\
\hline $\begin{array}{l}\text { Prior } \\
\text { Start-up } \\
\text { Exp }\end{array}$ & 1.21 & .407 & -.046 & -.053 & -.011 & 1 & $.124^{*}$ & -.011 & .025 & .092 & $.118^{*}$ \\
\hline $\begin{array}{c}\text { Prior } \\
\text { Work Exp }\end{array}$ & 1.81 & .394 & .017 & -.012 & $-.399^{* *}$ & $.124^{*}$ & 1 & -.043 & .034 & .011 & .038 \\
\hline $\begin{array}{c}\text { Family } \\
\text { business }\end{array}$ & 1.72 & .451 & -.035 & .027 & .050 & -.011 & -.043 & 1 & -.095 & -.062 & -.059 \\
\hline $\begin{array}{l}\text { Business } \\
\text { incubation }\end{array}$ & 3.25 & .826 & -.034 & -.036 & -.078 & .025 & .034 & -.095 & 1 & $.497^{* *}$ & $.452^{* *}$ \\
\hline $\mathrm{EO}$ & 3.84 & .925 & .057 & .015 & .009 & .092 & .011 & -.062 & $.497^{* *}$ & 1 & $.719^{* *}$ \\
\hline$A C$ & 3.80 & .970 & .020 & -.019 & -.078 & $.118^{*}$ & .038 & -.059 & $.452^{* *}$ & $.719^{* *}$ & 1 \\
\hline SP & 3.41 & .837 & .081 & -.066 & $-.132^{*}$ & .070 & .070 & -.071 & $.604^{* *}$ & $.674^{* *}$ & $.675^{* *}$ \\
\hline
\end{tabular}

**** $\mathrm{p}<0.001 ; \mathrm{N}=304,{ }^{*} \mathrm{p}<0.05 .,{ }^{* * *} \mathrm{p}<0.01$.

the number of years since the start-up was officially registered with the business incubators. Gender of the founding CEO was measured, as new ventures are often started by founders who will have an initial direct influence on the start-up decisions to innovate, and males are found to be more innovative than females. Here we have used binary variable "0" and " 1 ", respectively

Start-up founders with higher education may have better business performance as the founders can use their knowledge from formal education to better exploit resources, which results in better firm performance. We also controlled for prior start-up experience by measuring whether the founding CEO has previously started a new venture. Previous research advocates that prior start-up experience is a human capital dimension which can be a positive predictor of firm performance (Cooper et al., 1994; Nielsen, 2015). According to previous literature, prior work experience of the founding team also have a significant impact on small firm performance (Dyke et al., 1992; Ganotakis, 2012; Shaw et al., 2009). Family business and entrepreneurial family has a significant influence on start-up founders (Chang et al., 2009; Edelman et al., 2016). Prior start-up experience, prior work experience, and family entrepreneurial experience were represented using binary variables " 0 " and " 1 ".

The data-set was correctly prepared and reviewed for anomalies of regression modelling. Both univariate and multivariate outliers were missing and the ratio of cases to predictors fulfilled the guideline of Tabachnik \& Fidell (2007). Assumptions of multivariate statistics (linearity, normality, homogeneity) were also analyzed and determined satisfactory. The statistics of Shapiro-Wilk test and predicted residuals failed to indicate a violation of normality and linearity. We tried to reduce common method bias since each questionnaire was answered by a sole respondent. We also implemented corresponding control measures as suggested by Podsakoff et al. (2003). In line with our research design, participants were assured that their responses would be anonymous, that there would be no correct or incorrect answers, and that they would have to answer questions as fairly as possible. All the main variables were subjected to factor analysis and then assigned the number of factors that account for the variance in the measures. In addition, the reliability of scales was assessed with Cronbach's alpha. As shown in Table 2, all variables have reliability scores above 0.9 , and hence the subsequent step in the analysis could be performed.

\section{Results}

The means, standard deviations, and Pearson correlation coefficients of major variables are shown in Table 3 . The findings show that the associations between the main variables in the sample positive and related to each other. These are consistent with the above-mentioned hypotheses. In our regression models, all variance inflation factors (VIFs) were lower than 2, presenting no multicollinearity issues.

First, we show the results of hierarchical multiple regressions in Table 4 . We report the regression results of entrepreneurial orientation and start-up performance and absorptive capacity and start-up performance. From the hierarchical multiple regression results, we can further interpret the mediation effect, according to Baron\& Kenny (1986). If the mediation effect is present, then the effect of the independent variable reduces in size or even becomes insignificant. Model 1 involves only control variables, and Model 2 tests the effect of the independent variable entrepreneurial orientation $(\beta=.453, \mathrm{p}<.001)$ on start-up performance. On the basis of the two models, absorptive capacity ( $\beta=.431, \mathrm{p}<.001$ ) is added to the analysis. Compared with Model 2, the result of Models 3 indicates that absorptive capacity has a significant positive impact on start-up performance. The effects of Models 2-3 reveal that entrepreneur- 
Table 4: Results of Hierarchical multiple regressions

\begin{tabular}{|c|c|c|c|c|}
\hline & \multicolumn{4}{|c|}{ Start-up performance } \\
\hline & Model 1 & Model 2 & Model 3 & Model 4 \\
\hline Start-up Age & .164 & .084 & .135 & .099 \\
\hline Gender & -.131 & -.190 & -.134 & -.167 \\
\hline Education & -.138 & -.216 & -.096 & -.156 \\
\hline Prior Start-up Experience & .112 & .025 & .001 & -.010 \\
\hline Prior Work Experience & .033 & .023 & .040 & .032 \\
\hline Family business & -.010 & .004 & .002 & .006 \\
\hline Business Incubation & $.606^{* * *}$ & $.351^{* * *}$ & $.380^{* * *}$ & $.314^{* * *}$ \\
\hline EO & & $.453^{* * *}$ & & $.262^{* * *}$ \\
\hline$A C$ & & & $.431^{* * *}$ & $.276^{* * *}$ \\
\hline $\mathrm{R}^{2}$ & .385 & .569 & .580 & .616 \\
\hline Adjusted $\mathrm{R}^{2}$ & .372 & .558 & .570 & .606 \\
\hline$\Delta \mathrm{R}^{2}$ & & .184 & .011 & .036 \\
\hline $\mathrm{F}$ & $30.020^{* * *}$ & $55.214^{* * *}$ & $57.732^{* * *}$ & $59.497^{* * *}$ \\
\hline
\end{tabular}

${ }^{*} \mathrm{p}<0.05 .,{ }^{* * *} \mathrm{p}<0.01 .{ }^{* * * *} \mathrm{p}<0.001 ; \mathrm{N}=304$.

ial orientation and absorptive capacity have a significant impact on start-up performance. The above results support Hypothesis 1 and 2. Model 4 reveals the mediating effect, where both the independent variable and mediating variable are included in the meantime. The mediating effect of absorptive capacity on the relationship between entrepreneurial orientation and start-up performance is positive and significant $(\beta=.276, \mathrm{p}<.001)$. Therefore, Hypothesis 3 has been proved.

Further, to test the mediating relationship, a bootstrapping approach with 5,000 samples (Preacher \& Hayes, 2004) was utilized via the PROCESS macro in SPSS (Hayes, 2013). Overall, entrepreneurial orientation and absorptive capacity accounted for approximately $60 \%$ percent of the variance in start-up performance $(\mathrm{R} 2=.6025, \mathrm{p}<0.001)$. Results indicated that entrepreneurial orientation was a significant predictor of absorptive capacity $(\mathrm{b}=.6889$, s.e. $=.0449, \mathrm{p}<.001)$, and that absorptive capacity significantly predicted start-up performance $(b=.2870$, s.e. $=.0430, p<.001)$. Finally, a significant standardized indirect effect was observed (IE $=.1977$; $95 \% \mathrm{CI}=.1221, .2892)$. The results again support Hypothesis 3.

\section{Discussion and Implications}

This study tries to explore the effect and mechanism of entrepreneurial orientation on the performance of incubator start-ups in the Indian context. The findings are indicated as follows: Both the entrepreneurship strategy and learning ecosystem of start-ups affect their performance in an incubator environment. Wholly the five mechanisms of EO right from risk-taking behavior, innovativeness, pro-activeness, autonomy, and competitive aggressiveness reveals the potential of an entrepreneurially oriented firm to acquire and assimilate resources, which creates a direct and positive effect on entrepreneur learning as well as the per- formance of start-ups (Linton, 2019).

Further, the study shows that the effect of entrepreneurial orientation has varying characteristics due to the significant mediation of the dynamic capability of absorptive capacity. It means that business incubators should focus more on knowledge building networks to bring forth quality ventures which are high in EO. The study builds an understanding of the allied and coexisting factors involved in the incubation process, which is most significant in the strategy building, knowledge creation, and innovation among new firms. Consequently, integral to the success of startups is the mechanism by which an incubator firm deploys the services provided in the incubator to develop a substantial EO and ACAP, especially in early incubation stages. It is in those early stages that a crucial partnership is forged between the strategic and knowledge dimensions with the start-up venture (Kohtamäki et al., 2020; Lee et al., 2001; Linton, 2019).

On the other hand, to achieve high performance as well as to develop and maintain a strong competitive position, it is important for an upcoming firm to have adequate knowledge to sustain in the challenging dynamic market (Chaudhary, 2019; Sciascia et al., 2014). This study analyzes the role of absorptive capacity as a key knowledge construct that can influence firm performance and the level of EO. Our results show that absorptive capacity from the incubator network has a significant and positive influence on incubator firms. These results are consistent with prior general entrepreneurship studies indicating that the establishment of a supportive environment and enabling networks favor EO and the achievement of sustainable competitive advantage (Hou et al., 2019; M. Hughes et al., 2007, 2015; M. Hughes \& Morgan, 2007; Jiang et al., 2018; Wu et al., 2020). One of the major objectives of this study was to analyze the mediating effect of absorptive capacity on entrepreneurial orientation and the performance of incubator start-ups. And, hence the 
study shows a significant mediating effect of absorptive capacity, which is consistent with previous studies (Aljanabi, 2018; Hernández-Perlines \& Xu, 2018; Patel et al., 2015) in varying contexts, those of which have confirmed the mediating role of absorptive capacity. The findings of this study show that absorptive capacity as a dynamic capability enhances the effect of entrepreneurial orientation on start-up performance in an incubation context.

\subsection{Theoretical and Practical Implications}

Unlike previous research that focuses on the characteristics of business incubators (Grimaldi \& Grandi, 2005; Hackett \& Dilts, 2008; Voisey et al., 2006), this study highlights the content that flows through the relationship between an incubator and incubator firm, specifically the internal and external knowledge flow, and shows that absorptive capacity from business incubators helps start-ups develop their EO and consequently increase both hard and soft performance. Our study thus provides knowledge about how startups use these business incubators for competitive advantage. Although the type, model, and usage of services may differ among incubator firms (Voisey et al., 2006), as previous research suggests, the resources every start-up seek within incubators, and the use they make of these resources may be the same. This finding is also consistent with that of Voisey et al. (2006); Clausen \& Korneliussen (2012), which indicates that all start-ups receive a similar type of support from their business incubators, but excels differently due to their varying strategic and dynamic capabilities. Thus, the study has used the concept of strategic fit and theory of dynamic capabilities to develop the theoretical arguments concerning how a strategic capability like EO (Engelen et al., 2014)) can enhance start-up performance through a dynamic capability such as ACAP forming a flawless strategic fit. Empirical findings of our study indicate that ACAP enables the association between EO and start-up performance, in incubator environments, thereby addressing Clausen \& Korneliussen (2012) call for research on how to improve entrepreneurial orientation.

Nevertheless, as EO has a positive and direct influence on ACAP, which in turn positively and directly influences start-up performance, we can infer that EO has an indirect positive influence on a firm's financial performance through ACAP. This suggests that it is the innovative and proactive combination of the knowledge acquired that leads to superior financial performance. And this result is in line with previous research, such as that of Wiklund \& Shepherd (2003), which emphasizes that entrepreneurial combination by themselves do not explain the creation of competitive advantage; it is the knowledge-based resources that contribute to generating competitive advantage (El Hanchi \& Kerzazi, 2020). As EO is a way of combining resources with positive outcomes for firm performance (Jiang et al., 2018; Wiklund \& Shepherd, 2003), it represents a means of translating the benefits of absorptive capacity into superior performance (Chaudhary, 2019; P. Hughes et al., 2018).

Theoretically, the results of this research contribute to advancing knowledge in areas of knowledge-based view of dynamic capabilities, and the concept of strategic fit: the relationship between EO and incubator firm performance, and the absorptive capacity of start-ups in incubators. Regarding the first stream of literature, the results obtained show that EO has a significant influence on the hard and soft performance of incubator firms, emphasizing the importance of developing an EO to improve the results of these firms, particularly the commercial results. These findings confirm that EO constitutes a key performance driver in small firms operating in unstable, technological sectors that are working under significant resource restrictions (Park \& Xiao, 2020; Wiklund \& Shepherd, 2003). Our study finds place along with the previous studies on EO, which suggests that businesses are operating in dynamic industries where technology change rapidly are most likely to benefit from entrepreneurial initiatives (Rauch et al. 2009). From this perspective, incubator firms constitute a specific, noteworthy sampling for the study of the relationship between EO and firm performance; they are concentrated primarily in the technology sectors, where businesses matter in terms of investment, employment, revenues, and growth (Clausen \& Korneliussen, 2012; Gertner \& Mack, 2017; M. Hughes \& Morgan, 2007; Walter et al., 2006; Wu et al., 2020). Additionally, we differ from previous studies by proving that EO has a significant effect on both the financial and non-financial measures of start-up firm performance.

The key result of this work is that entrepreneurial orientation is undoubtedly proved as a key factor of start-up firm performance, with implications for the management of incubator start-ups. Using this model, they can determine the mechanisms of entrepreneurial orientation to be carried out to improve their results. The entrepreneurial orientation of incubator start-ups in terms of their innovativeness, proactiveness, risk propensity, nature of competition, and room for autonomy determines their capacity to explore, transform, and exploit new knowledge. Entrepreneurial orientation affects the type of innovation strategies adopted by incubator firms (M. Hughes et al., 2007; Kohtamäki et al., 2020; Shi et al., 2020), the way incubator firms address these strategies in terms of decision making. This role of entrepreneurial orientation as an antecedent of absorptive capacity has been highlighted in prior studies (Aljanabi, 2018), but not in the context of incubators. This study presents a new performance model for incubators and incubator firms. Thus, incubator firms can improve their performance with the intervention of absorptive capacity in the relationship between entrepreneurial orientation and performance. This finding allows managers of incubators and incubator start-ups to determine how they should use their dynamic capabilities to improve the effect of entrepreneurial orientation on incubator start-up performance, designing relevant mechanisms for exploration, transformation, and exploitation of new knowledge.

Incubator firms and incubator managers should act to stimulate the knowledge acquisition from incubators as a way of reducing limitations in the technological or market knowledge endowments of the firms. They should also act to establish routines and procedures that help them to exploit the knowledge acquired from incubator networks for entrepreneurial purposes; these resources positively impact both the hard and soft performance of their firms and, when combined entrepreneurially, also enhance their economic performance altogether. Incubator firms should also be 
aware that active seeking for new entrepreneurial opportunities, by assuming the risks associated by way of autonomy through proactive and innovative initiatives in a competing environment, is a key factor for the success of their firms. In this sense, the interactive context of their firms constitutes an important source of inspiration and support for such initiatives.

This research also has implications for active public policies aiming to support business incubators. Policies should stimulate the ACAP in incubator firms not only by providing resources but also by helping start-ups to use those resources in an entrepreneurially oriented way. For example, the stimulation of collaborative business, university, and international networks by incubators acting as catalysts or the promotion of knowledge exchanges between firms and joint knowledge-generating activities can support and encourage entrepreneurial initiatives in incubator firms, as well as enhance their performance.

\section{Limitations and Future research}

Quite a lot of research implications and, at the same time, quite a few limitations have also emerged from our study. The study is limited to analyzing the effect of entrepreneurial orientation alongside absorptive capacity on startup performance among government-supported technology business incubator firms at a single point of time. In a cross-sectional study like ours, the issue of causality is unavoidable. Thus, an important extension of this study would be longitudinal studies of the relationship between entrepreneurial orientation and startup performance.
A larger sample and higher response rate would give greater weight to the results obtained and would permit the performance of sectoral analyses that would refine these results. Nevertheless, given the lack of data on these types of firms, this research can be considered a first approach that needs to be validated in other samples and contexts.

This research is performed in a specific setting in one country (India). Business incubation services may vary based on the country context, and hence factors influencing startup performance may vary accordingly. Therefore, generalizations should be made by conducting comparative studies pertaining to incubator start-up performance encompassing entrepreneurial orientation and absorptive capacity in order to understand whether our study findings hold in varying country contexts. Studies comparing incubator start-ups with other types of firms in other countries would also be valuable to investigate significant differences with respect to the results of the present study.

Another avenue that could be explored in future research is the analysis of moderator variables in the relationship between EO and performance. Future studies should explore to what extent the results obtained are contingent on several moderator variables, such as the resources and capabilities owned Wiklund \& Shepherd (2003).

An additional possibility that could be explored in future research is to consider the multi-dimensional nature of EO, so as to try and determine which factor of EO contributes more to performance among incubator firms and how the effect of specific dimensions on ACAP can be looked upon individually by incubator managers for improved performance. 


\section{REFERENCES}

del Mar Fuentes-Fuentes, M., Bojica, A. M., \& RuizArroyo, M. (2015). Entrepreneurial orientation and knowledge acquisition: Effects on performance in the specific context of women-owned firms. International Entrepreneurship and Management Journal, 11(3), 695-717. https://doi.org/10.1007/s11365-014-0336-1

Aernoudt, R. (2004). Incubators: tool for entrepreneurship? Small Business Economics, 23(2), 127-135. https://doi.org/10.1023/b:sbej.000002766 5.54173.23

Aljanabi, A. R. A. (2018). The mediating role of absorptive capacity on the relationship between entrepreneurial orientation and technological innovation capabilities. International Journal of Entrepreneurial Behavior \& Research, 24(4), 818-841. https://doi.org/10.1108/ijebr-07-2017-0233

Al-Mubaraki, H. M., \& Busler, M. (2013). Business incubation as an economic development strategy: A literature review. International Journal of Management, 30(1), 362-373.

Ambrosini, V., Bowman, C., \& Collier, N. (2009). Dynamic capabilities: An exploration of how firms renew their resource base. British Journal of Management, 20, S9-S24. https://doi.org/10.1111/j.14 67-8551.2008.00610.x

Argote, L., McEvily, B., \& Reagans, R. (2003). Managing knowledge in organizations: An integrative framework and review of emerging themes. Management Science, 49(4), 571-582. https://doi.org/1 0.1287/mnsc.49.4.571.14424

Ayatse, F. A., Kwahar, N., \& Iyortsuun, A. S. (2017). Business incubation process and firm performance: An empirical review. Journal of Global Entrepreneurship Research, 7(1), 2. https://doi.org/1 0.1186/s40497-016-0059-6

Barreto, I. (2010). Dynamic capabilities: A review of past research and an agenda for the future. Journal of Management, 36(1), 256-280. https://doi.org/10.1177/ 0149206309350776

Becker, B., \& Gassmann, O. (2006). Gaining leverage effects from knowledge modes within corporate incubators. $R$ \& D Management, 36(1), 1-16. https://d oi.org/10.1111/j.1467-9310.2005.00411.x

Bradley, S. W., McMullen, J. S., Artz, K., \& Simiyu, E. M. (2012). Capital is not enough: Innovation in developing economies. Journal of Management Studies, 49(4), 684-717. https://doi.org/10.1111/j.1467-6486.2 012.01043.X

Campbell, C., \& Allen, D. N. (1987). The small business incubator industry: Micro-level economic development. Economic Development Quarterly, 1(2), 178-191. https://doi.org/10.1177/0891242487001002 09
Carayannis, E. G., \& Von Zedtwitz, M. (2005). Architecting gloCal (global-local), real-virtual incubator networks (G-RVINs) as catalysts and accelerators of entrepreneurship in transitioning and developing economies: Lessons learned and best practices from current development and business incubation practices. Technovation, 25(2), 95-110. htt ps://doi.org/10.1016/s0166-4972(03)00072-5

Caseiro, N., \& Coelho, A. (2019). The influence of Business Intelligence capacity, network learning and innovativeness on startups performance. Journal of Innovation \& Knowledge, 4(3), 139-145. https://doi.or g/10.1016/i.jik.2018.03.009

Chang, E. P. C., Memili, E., Chrisman, J. J., Kellermanns, F. W., \& Chua, J. H. (2009). Family social capital, venture preparedness, and start-up decisions: A study of Hispanic entrepreneurs in New England. Family Business Review, 22(3), 279-292. https://doi.org/10.11 77/0894486509332327

Chaudhary, S. (2019). Implications of strategic flexibility in small firms: The moderating role of absorptive capacity. South Asian Journal of Business Studies, 8(3), 370-386. https://doi.org/10.1108/sajbs-10-2018-0104

Chen, C.-J. (2009). Technology commercialization, incubator and venture capital, and new venture performance. Journal of Business Research, 62(1), 93-103. https://doi.org/10.1016/j.jbusres.2008.01.003

Chen, Y.-S., Lin, M.-J. J., \& Chang, C.-H. (2009). The positive effects of relationship learning and absorptive capacity on innovation performance and competitive advantage in industrial markets. Industrial Marketing Management, 38(2), 152-158. htt ps://doi.org/10.1016/j.indmarman.2008.12.003

Clausen, T., \& Korneliussen, T. (2012). The relationship between entrepreneurial orientation and speed to the market: The case of incubator firms in Norway. Technovation, 32(9-10), 560-567. https://doi.org/10.1 016/i.technovation.2012.05.004

Cohen, W. M., \& Levinthal, D. A. (1990). Absorptive capacity: A new perspective on learning and innovation. Administrative Science Quarterly, 35(1), 128-152. https://doi.org/10.2307/2393553

Colbert, B. A. (2004). The complex resource-based view: Implications for theory and practice in strategic human resource management. Academy of Management Review, 29(3), 341-358. https://doi.org/1 0.5465/amr.2004.13670987

Cooper, A. C., Gimeno-Gascon, F. J., \& Woo, C. Y. (1994). Initial human and financial capital as predictors of new venture performance. Journal of Business Venturing, 9(5), 371-395. https://doi.org/10.1 016/0883-9026(94)90013-2

Coulthard, M. (2007). The role of entrepreneurial orientation on firm performance and the potential influence of relational dynamism. Monash University Faculty of Business and Economics. 
Covin, J. G., \& Miles, M. P. (1999). Corporate entrepreneurship and the pursuit of competitive advantage. Entrepreneurship Theory and Practice, 23(3), 47-63. https://doi.org/10.1177/1042258799023 $\underline{00304}$

Covin, J. G., \& Miller, D. (2014). International entrepreneurial orientation: Conceptual considerations, research themes, measurement issues, and future research directions.

Entrepreneurship Theory and Practice, 38(1), 11-44. ht tps://doi.org/10.1111/etap.12027

Davidsson, P. (2015). Entrepreneurial opportunities and the entrepreneurship nexus: A re-conceptualization. Journal of Business Venturing, 30(5), 674-695. http s://doi.org/10.1016/j.jbusvent.2015.01.002

Dess, G. G., \& Lumpkin, G. T. (2005). The role of entrepreneurial orientation in stimulating effective corporate entrepreneurship. Academy of Management Perspectives, 19(1), 147-156. https://doi.org/10.5465/a $\underline{\text { me.2005.15841975 }}$

Dess, G. G., Lumpkin, G. T., \& Covin, J. G. (1997). Entrepreneurial strategy making and firm performance: Tests of contingency and configurational models. Strategic Management Journal, 18(9), 677-695. https://doi.org/10.1002/(sic i)1097-0266(199710)18:9

Dimov, D. P., \& Shepherd, D. A. (2005). Human capital theory and venture capital firms: Exploring "home runs" and "strike outs." Journal of Business Venturing, 20(1), 1-21. https://doi.org/10.1016/i.jbusvent.2003.1 $\underline{2.007}$

Dyke, L. S., Fischer, E. M., \& Reuber, A. R. (1992). An inter-industry examination of the impact of owner experience on firm performance. Journal of Small Business Management, 30(4), 72.

Ebrahimi, P., Shafiee, B., Gholampour, A., \& Yousefi, L. (2018). Impact of organizational innovation, learning orientation and entrepreneurship on SME performance: The moderating role of market turbulence and ICT. In Competitiveness in Emerging Markets (pp. 447-480). Springer International Publishing. https://doi.org/10.1007/978-3-319-7172 2-7_23

Edelman, L. F., Manolova, T., Shirokova, G., \& Tsukanova, T. (2016). The impact of family support on young entrepreneurs' start-up activities. Journal of Business Venturing, 31(4), 428-448. https://doi.org/1 0.1016/j.jbusvent.2016.04.003

Eisenhardt, K. M., \& Schoonhoven, C. B. (1996). Resource-based view of strategic alliance formation: Strategic and social effects in entrepreneurial firms. Organization Science, 7(2), 136-150. https://doi.org/1 $\underline{0.1287 / \text { orsc.7.2.136 }}$

El Hanchi, S., \& Kerzazi, L. (2020). Startup innovation capability from a dynamic capability-based view: A literature review and conceptual framework. Journal of Small Business Strategy, 30(2), 72-92.

Engelen, A., Kube, H., Schmidt, S., \& Flatten, T. C. (2014). Entrepreneurial orientation in turbulent environments: The moderating role of absorptive capacity. Research Policy, 43(8), 1353-1369. https://do i.org/10.1016/j.respol.2014.03.002
Fayolle, A., Basso, O., \& Bouchard, V. (2010). Three levels of culture and firms' entrepreneurial orientation: A research agenda. Entrepreneurship \& Regional Development, 22(7-8), 707-730. https://doi.o rg/10.1080/08985620903233952

Fitza, M., Matusik, S. F., \& Mosakowski, E. (2009). Do VCs matter? the importance of owners on performance variance in start-up firms. Strategic Management Journal, 30(4), 387-404. https://doi.org/1 $\underline{0.1002 / \mathrm{smj} .748}$

Flatten, T. C., Greve, G. I., \& Brettel, M. (2011). Absorptive capacity and firm performance in SMEs: The mediating influence of strategic alliances. European Management Review, 8(3), 137-152. http s://doi.org/10.1111/j.1740-4762.2011.01015.x

Franco, M., \& Haase, H. (2013). Firm resources and entrepreneurial orientation as determinants for collaborative entrepreneurship. Management Decision, 51(3), 680-696. https://doi.org/10.1108/00251741311 $\underline{309724}$

Ganotakis, P. (2012). Founders' human capital and the performance of UK new technology based firms. Small Business Economics, 39(2), 495-515. https://doi.org/1 0.1007/s11187-010-9309-0

Gebauer, H., Worch, H., \& Truffer, B. (2012). Absorptive capacity, learning processes and combinative capabilities as determinants of strategic innovation. European Management Journal, 30(1), 57-73. https://d oi.org/10.1016/j.emj.2011.10.004

George, G., \& Bock, A. J. (2011). The business model in practice and its implications for entrepreneurship research. Entrepreneurship Theory and Practice, 35(1), 83-111. https://doi.org/10.1111/j.1540-6520.2010.00 424.x

Gertner, D., \& Mack, E. (2017). The Entrepreneurial Orientation (EO) of incubators, accelerators, and coworking spaces. International Journal of Regional Development, 4(2), 1. https://doi.org/10.5296/ijrd.v4i $\underline{2.10210}$

Grandinetti, R. (2016). Absorptive capacity and knowledge management in small and medium enterprises. Knowledge Management Research \& Practice, 14(2), 159-168. https://doi.org/10.1057/kmr p.2016.2

Grant, R. M. (1996). Toward a knowledge-based theory of the firm. Strategic Management Journal, 17(S2), 109-122. https://doi.org/10.1002/smj.4250171110

Green, K. M., Covin, J. G., \& Slevin, D. P. (2008). Exploring the relationship between strategic reactiveness and entrepreneurial orientation: The role of structure-style fit. Journal of Business Venturing, 23(3), 356-383. https://doi.org/10.1016/j.jb usvent.2007.01.002

Grimaldi, R., \& Grandi, A. (2005). Business incubators and new venture creation: An assessment of incubating models. Technovation, 25(2), 111-121. htt ps://doi.org/10.1016/s0166-4972(03)00076-2

Hackett, S. M., \& Dilts, D. M. (2004a). A real optionsdriven theory of business incubation. The Journal of Technology Transfer, 29(1), 41-54. https://doi.org/10.1 023/b:jott.0000011180.19370.36 
Hackett, S. M., \& Dilts, D. M. (2004b). A systematic review of business incubation research. The Journal of Technology Transfer, 29(1), 55-82. https://doi.org/10.1 023/b:jott.0000011181.11952.0f

Hackett, S. M., \& Dilts, D. M. (2008). Inside the black box of business incubation: Study B-scale assessment, model refinement, and incubation outcomes. The Journal of Technology Transfer, 33(5), 439-471. https://doi.org/10.1007/s10961-007-9056-9

Harrison, E. F., \& Pelletier, M. A. (1998). Foundations of strategic decision effectiveness. Management Decision, 36(3), 147-159. https://doi.org/10.1108/002 $\underline{51749810208931}$

Hernández-Perlines, F., \& Xu, W. (2018). Conditional mediation of absorptive capacity and environment in international entrepreneurial orientation of family businesses. Frontiers in Psychology, 9, 102. https://do i.org/10.3389/fpsyg.2018.00102

Hopp, C., \& Stephan, U. (2012). The influence of sociocultural environments on the performance of nascent entrepreneurs: Community culture, motivation, selfefficacy and start-up success. Entrepreneurship \& Regional Development, 24(9-10), 917-945. https://do i.org/10.1080/08985626.2012.742326

Hou, B., Hong, J., \& Zhu, R. (2019). Exploration/ exploitation innovation and firm performance: The mediation of entrepreneurial orientation and moderation of competitive intensity. Journal of Asia Business Studies, 13(4), 489-506. https://doi.org/10.11 08/jabs-11-2017-0206

Hughes, M., Eggers, F., Kraus, S., \& Hughes, P. (2015). The relevance of slack resource availability and networking effectiveness for entrepreneurial orientation. International Journal of Entrepreneurship and Small Business, 26(1), 116. https://doi.org/10.150 4/ijesb.2015.071323

Hughes, M., Hughes, P., \& Morgan, R. E. (2007). Exploitative learning and entrepreneurial orientation alignment in emerging young firms: Implications for market and response performance. British Journal of Management, 18(4), 359-375. https://doi.org/10.1111/ j.1467-8551.2007.00519.x

Hughes, M., \& Morgan, R. E. (2007). Deconstructing the relationship between entrepreneurial orientation and business performance at the embryonic stage of firm growth. Industrial Marketing Management, 36(5), 651-661. https://doi.org/10.1016/j.indmarman.2006.0 $\underline{4.003}$

Hughes, P., Hodgkinson, I. R., Hughes, M., \& Arshad, D. (2018). Explaining the entrepreneurial orientation-performance relationship in emerging economies: The intermediate roles of absorptive capacity and improvisation. Asia Pacific Journal of Management, 35(4), 1025-1053. https://doi.org/10.10 07/s10490-017-9539-7

Hutabarat, Z., \& Pandin, M. (2014). Absorptive capacity of business incubator for SME's rural community located in indonesia's village. Procedia - Social and Behavioral Sciences, 115(2/21), 373-377. https://doi.or $\mathrm{g} / 10.1016 / \mathrm{j}$. sbspro.2014.02.443
Iyortsuun, A. S. (2017). An empirical analysis of the effect of business incubation process on firm performance in Nigeria. Journal of Small Business \& Entrepreneurship, 29(6), 433-459. https://doi.org/10.1 080/08276331.2017.1376265

Jansen, J. J. P., Van Den Bosch, F. A. J., \& Volberda, H. W. (2005). Managing potential and realized absorptive capacity: How do organizational antecedents matter? Academy of Management Journal, 48(6), 999-1015. htt ps://doi.org/10.5465/amj.2005.19573106

Jiang, X., Liu, H., Fey, C., \& Jiang, F. (2018). Entrepreneurial orientation, network resource acquisition, and firm performance: A network approach. Journal of Business Research, 87, 46-57. htt ps://doi.org/10.1016/j.jbusres.2018.02.021

Keh, H. T., Nguyen, T. T. M., \& Ng, H. P. (2007). The effects of entrepreneurial orientation and marketing information on the performance of SMEs. Journal of Business Venturing, 22(4), 592-611. https://doi.org/1 0.1016/j.jbusvent.2006.05.003

Khedhaouria, A., Gurău, C., \& Torrès, O. (2015). Creativity, self-efficacy, and small-firm performance: The mediating role of entrepreneurial orientation. Small Business Economics, 44(3), 485-504. https://do i.org/10.1007/s11187-014-9608-y

Kim, Y. J., Song, S., Sambamurthy, V., \& Lee, Y. L. (2012). Entrepreneurship, knowledge integration capability, and firm performance: An empirical study. Information Systems Frontiers, 14(5), 1047-1060. http s://doi.org/10.1007/s10796-011-9331-z

Kintsch, W. (1988). The role of knowledge in discourse comprehension: A construction-integration model. Psychological Review, 95(2), 163-182. https://doi.org/1 $\underline{0.1037 / 0033-295 x .95 .2 .163}$

Kohtamäki, M., Heimonen, J., Sjödin, D., \& Heikkilä, V. (2020). Strategic agility in innovation: Unpacking the interaction between entrepreneurial orientation and absorptive capacity by using practice theory. Journal of Business Research, 118, 12-25. https://doi.org/10.10 16/j.jbusres.2020.06.029

Kraus, S., Rigtering, J. P. C., Hughes, M., \& Hosman, V. (2012). Entrepreneurial orientation and the business performance of SMEs: A quantitative study from the Netherlands. Review of Managerial Science, 6(2), 161-182. https://doi.org/10.1007/s11846-011-0062-9

Lane, P. J., Koka, B. R., \& Pathak, S. (2006). The reification of absorptive capacity: A critical review and rejuvenation of the construct. Academy of Management Review, 31(4), 833-863. https://doi.org/1 0.5465/amr.2006.22527456

Lechner, C., \& Gudmundsson, S. V. (2014). Entrepreneurial orientation, firm strategy and small firm performance. International Small Business Journal, 32(1), 36-60. https://doi.org/10.1177/026624 2612455034

Lee, C., Lee, K., \& Pennings, J. M. (2001). Internal capabilities, external networks, and performance: A study on technology-based ventures. Strategic Management Journal, 22(6-7), 615-640. https://doi.or $\mathrm{g} / 10.1002 /$ smj. 181 
Lewrick, M., Omar, M., \& Williams, Jr, R. L. (2011). Market orientation and innovators' success: An exploration of the influence of customer and competitor orientation. Journal of Technology Management \& Innovation, 6(3), 48-62. https://doi.or $\mathrm{g} / 10.4067 / \mathrm{s} 0718-27242011000300004$

Li, Y.-H., Huang, J.-W., \& Tsai, M.-T. (2009). Entrepreneurial orientation and firm performance: The role of knowledge creation process. Industrial Marketing Management, 38(4), 440-449. https://doi.or g/10.1016/j.indmarman.2008.02.004

Linton, G. (2019). Innovativeness, risk-taking, and proactiveness in startups: A case study and conceptual development. Journal of Global Entrepreneurship Research, 9(1), 1-21. https://doi.org/ 10.1186/s40497-019-0147-5

Lumpkin, G. T., \& Dess, G. G. (1996). Clarifying the entrepreneurial orientation construct and linking it to performance. The Academy of Management Review, 21(1), 135. https://doi.org/10.2307/258632

Lumpkin, G. T., \& Dess, G. G. (2001). Linking two dimensions of entrepreneurial orientation to firm performance: The moderating role of environment and industry life cycle. Journal of Business Venturing, 16(5), 429-451. https://doi.org/10.1016/s0883-9026(0 0)00048-3

Lyon, D. W., Lumpkin, G. T., \& Dess, G. G. (2000). Enhancing entrepreneurial orientation research: Operationalizing and measuring a key strategic decision making process. Journal of Management, 26(5), 1055-1085. https://doi.org/10.1177/014920630 002600503

Madsen, E. L. (2007). The significance of sustained entrepreneurial orientation on performance of firms - A longitudinal analysis. Entrepreneurship \& Regional Development, 19(2), 185-204. https://doi.org/ 10.1080/08985620601136812

Mavondo, F. T., Chimhanzi, J., \& Stewart, J. (2005). Learning orientation and market orientation. European Journal of Marketing, 39(11/12), 1235-1263. https://doi.org/10.1108/03090560510623244

Miles, M. P., \& Arnold, D. R. (1991). The relationship between marketing orientation and entrepreneurial orientation. Entrepreneurship Theory and Practice, 15(4), 49-66. https://doi.org/10.1177/1042258791015 00407

Miller, D. (2011). Miller (1983) revisited: A reflection on EO research and some suggestions for the future. Entrepreneurship Theory and Practice, 35(5), 873-894. https://doi.org/10.1111/j.1540-6520.2011.00457.x

Monteiro, A. P., Soares, A. M., \& Rua, O. L. (2019). Linking intangible resources and entrepreneurial orientation to export performance: The mediating effect of dynamic capabilities. Journal of Innovation \& Knowledge, 4(3), 179-187. https://doi.org/10.1016/i.ji k.2019.04.001

Newbert, S. L. (2008). Value, rareness, competitive advantage, and performance: A conceptual-level empirical investigation of the resource-based view of the firm. Strategic Management Journal, 29(7), 745-768. https://doi.org/10.1002/smi.686
Nielsen, K. (2015). Human capital and new venture performance: The industry choice and performance of academic entrepreneurs. The Journal of Technology Transfer, 40(3), 453-474. https://doi.org/10.1007/s109 61-014-9345-Z

Omisakin, O. M., Nakhid, C., Littrell, R., \& Verbitsky, J. (2016). Entrepreneurial orientation among migrants and small and medium enterprises. Journal of Business Administration Research, 5(1). https://doi.org/10.5430/ jbar.v5n1p7

Park, B. I., \& Xiao, S. (2020). Is exploring dynamic capabilities important for the performance of emerging market firms? The moderating effects of entrepreneurial orientation and environmental dynamism. International Studies of Management \& Organization, 50(1), 57-73. https://doi.org/10.1080/00 208825.2019.1703378

Patel, P. C., Kohtamäki, M., Parida, V., \& Wincent, J. (2015). Entrepreneurial orientation-asexperimentation and firm performance: The enabling role of absorptive capacity. Strategic Management Journal, 36(11), 1739-1749. https://doi.org/10.1002/s mj.2310

Patton, D. (2014). Realising potential: The impact of business incubation on the absorptive capacity of new technology-based firms. International Small Business Journal, 32(8), 897-917. https://doi.org/10.1177/02662 42613482134

Pelham, A. M., \& Wilson, D. T. (1995). A longitudinal study of the impact of market structure, firm structure, strategy, and market orientation culture on dimensions of small-firm performance. Journal of the Academy of Marketing Science, 24(1), 27-43. https://do i.org/10.1177/009207039602400103

Pena, I. (2002). Intellectual capital and business start - up success. Journal of Intellectual Capital.

Pena, I. (2004). Business incubation centers and new firm growth in the Basque country. Small Business Economics, 22(3-4), 223-236. https://doi.org/10.1023/ b:sbej.0000022221.03667.82

Podsakoff, P. M., MacKenzie, S. B., Lee, J.-Y., \& Podsakoff, N. P. (2003). Common method biases in behavioral research: A critical review of the literature and recommended remedies. Journal of Applied Psychology, 88(5), 879-903. https://doi.org/10.1037/0 021-9010.88.5.879

Polonsky, M. J., Voss, Z. G., Voss, G. B., \& Moorman, C. (2005). An empirical examination of the complex relationships between entrepreneurial orientation and stakeholder support. European Journal of Marketing.

Renko, M., Carsrud, A., \& Brännback, M. (2009). The effect of a market orientation, entrepreneurial orientation, and technological capability on innovativeness: A study of young biotechnology ventures in the United States and in Scandinavia. Journal of Small Business Management, 47(3), 331-369. https://doi.org/10.1111/i.1540-627x.2009.00274.x

Roberts, N. (2015). Absorptive capacity, organizational antecedents, and environmental dynamism. Journal of Business Research, 68(11), 2426-2433. https://doi.org/ 10.1016/j.jbusres.2015.02.019 
Runyan, R., Droge, C., \& Swinney, J. (2008). Entrepreneurial orientation versus small business orientation: What are their relationships to firm performance? Journal of Small Business Management, 46(4), 567-588. https://doi.org/10.1111/j.1540-627x.2 008.00257.x

Schwartz, M. (2013). A control group study of incubators' impact to promote firm survival. The Journal of Technology Transfer, 38(3), 302-331. http s://doi.org/10.1007/s10961-012-9254-y

Sciascia, S., D’oria, L., Bruni, M., \& Larrañeta, B. (2014). Entrepreneurial Orientation in low- and mediumtech industries: The need for Absorptive Capacity to increase performance. European Management Journal, 32(5), 761-769. https://doi.org/10.1016/j.emj.2013.1 $\underline{2.007}$

Shaw, E., Marlow, S., Lam, W., \& Carter, S. (2009). Gender and entrepreneurial capital: Implications for firm performance. International Journal of Gender and Entrepreneurship, 1(1), 25-41. https://doi.org/10.110 8/17566260910942327

Shi, Z., Yuan, L., \& Lee, S. H. (2020). Dynamic capabilities and entrepreneurial performance of Chinese start-ups: The mediating roles of managerial attitude towards risk and entrepreneurial behaviour. Asia Pacific Business Review, 1-26.

Stam, W., \& Elfring, T. (2008). Entrepreneurial Orientation and New Venture Performance: The Moderating Role of Intra- And Extraindustry Social Capital. Academy of Management Journal, 51(1), 97-111. https://doi.org/10.5465/amj.2008.30744031

Tabachnik, B. G., \& Fidell, S. L. (2007). Discriminant analysis. Using multivariate statistics. Pearson Education Inc.

Taormina, R. J., \& Lao, S. K. (2007). Measuring Chinese entrepreneurial motivation. International Journal of Entrepreneurial Behavior \& Research, 13(4), 200-221. https://doi.org/10.1108/13552550710759997

Theriou, N., Aggelidia, V., \& Theriou, G. (2009). A theoretical framework contrasting the resource-based perspective and the knowledge-based view.

Theriou, N., Aggelidis, V., \& Theriou, G. (2014). The mediating effect of the knowledge management process to the firm's performance: A resource-based view. International Journal of Economics and Business Administration, II(Issue 1), 87-114. https://doi.org/1 $\underline{0.35808 / \mathrm{ijeba} / 36}$

Tsai, F.-S., Hsieh, L. H. Y., Fang, S.-C., \& Lin, J. L. (2009). The co-evolution of business incubation and national innovation systems in Taiwan. Technological Forecasting and Social Change, 76(5), 629-643. http s://doi.org/10.1016/i.techfore.2008.08.009

Tzokas, N., Kim, Y. Ah., Akbar, H., \& Al-Dajani, H. (2015). Absorptive capacity and performance: The role of customer relationship and technological capabilities in high-tech SMEs. Industrial Marketing Management, 47, 134-142. https://doi.org/10.1016/j.i ndmarman.2015.02.033
Vanderstraeten, J., \& Matthyssens, P. (2010). Measuring the performance of business incubators: A critical analysis of effectiveness approaches and performance measurement systems (ICSB World Conference Proceedings, p. 1). International Council for Small Business (ICSB).

Vanhaverbeke, W., Vermeersch, I., \& De Zutter, S. (2012). Open innovation in SME's: How can small companies and start-ups benefit from open innovation strategies?

Venkatraman, N., \& Ramanujam, V. (1986). Measurement of business performance in strategy research: A comparison of approaches. The Academy of Management Review, 11(4), 801. https://doi.org/10.2 $\underline{307 / 258398}$

Voisey, P., Gornall, L., Jones, P., \& Thomas, B. (2006). The measurement of success in a business incubation project. Journal of Small Business and Enterprise Development, 13(3), 454-468. https://doi.org/10.1108/ $\underline{14626000610680307}$

Wales, W. J., Parida, V., \& Patel, P. C. (2013). Too much of a good thing? Absorptive capacity, firm performance, and the moderating role of entrepreneurial orientation. Strategic Management Journal, 34(5), 622-633. https://doi.org/10.1002/smj.2 $\underline{026}$

Walter, A., Auer, M., \& Ritter, T. (2006). The impact of network capabilities and entrepreneurial orientation on university spin-off performance. Journal of Business Venturing, 21(4), 541-567. https://doi.org/1 $\underline{0.1016 / j . j b u s v e n t .2005 .02 .005}$

Wang, C. L. (2008). Entrepreneurial orientation, learning orientation, and firm performance. Entrepreneurship Theory and Practice, 32(4), 635-657. https://doi.org/10.1111/j.1540-6520.2008.00246.x

West, G. P., III, \& Meyer, G. D. (1998). To agree or not to agree? Consensus and performance in new ventures. Journal of Business Venturing, 13(5), 395-422. http s://doi.org/10.1016/s0883-9026(97)00037-2

Wiklund, J., \& Shepherd, D. (2003). Knowledge-based resources, entrepreneurial orientation, and the performance of small and medium-sized businesses. Strategic Management Journal, 24(13), 1307-1314. htt ps://doi.org/10.1002/smj.360

Wu, W., Wang, H., \& Tsai, F.-S. (2020). Incubator networks and new venture performance: The roles of entrepreneurial orientation and environmental dynamism. Journal of Small Business and Enterprise Development, 27(5), 727-747. https://doi.org/10.1108/i sbed-10-2019-0325

Yamakawa, Y., Yang, H., \& Lin, Z. J. (2011). Exploration versus exploitation in alliance portfolio: Performance implications of organizational, strategic, and environmental fit. Research Policy, 40(2), 287-296. htt ps://doi.org/10.1016/j.respol.2010.10.006

Yli-Renko, H., Autio, E., \& Tontti, V. (2002). Social capital, knowledge, and the international growth of technology-based new firms. International Business Review, 11(3), 279-304. https://doi.org/10.1016/s096 9-5931(01)00061-0 
Zahra, S. A., \& George, G. (2002). Absorptive capacity: A review, reconceptualization, and extension. The Academy of Management Review, 27(2), 185. https://do i.org/10.2307/4134351
Zahra, S. A., \& Hayton, J. C. (2008). The effect of international venturing on firm performance: The moderating influence of absorptive capacity. Journal of Business Venturing, 23(2), 195-220. https://doi.org/ 10.1016/j.jbusvent.2007.01.001 